\title{
Ko-infeksi Tuberkulosis dan HIV pada Anak
}

\author{
Retno Widyaningsih, Amar Widhiani, Endah Citraresmi \\ SMF Anak RSAB Harapan Kita, Jakarta
}

\begin{abstract}
Latar belakang. Tuberkulosis (TB) adalah infeksi oportunistik yang sering menjadi ko-infeksi HIV. Diagnosis dan manajemen TB anak menimbulkan tantangan substansial dalam era epidemi HIV. Diagnosis TB pada anak semakin dipersulit oleh adanya ko-infeksi HIV.

Tujuan penelitian. Penelitian ini bertujuan untuk mengetahui karakteristik TB pada anak dengan infeksi HIV di RSAB Harapan Kita Jakarta.

Metode. Penelitian ini menggunakan desain potong lintang. Data berasal dari rekam medis pasien HIVTB di RSAB Harapan Kita tahun 2002-2010. Kriteria inklusi adalah anak yang berumur 0-12 tahun, HIV positif dan menderita penyakit TB. Data meliputi faktor risiko infeksi dan sakit TB yaitu umur, parut BCG, kontak dengan penderita TB, status gizi, dan status imunitas HIV. Data lain yang dicatat yaitu gejala klinis HIV dan gejala klinis TB, pemeriksaan laboratorium, foto Rontgen toraks, pengobatan serta outcome.

Hasil. Sebanyak 50 anak terdiagnosis infeksi HIV. Dua puluh tujuh anak (54\%) menderita penyakit TB, dengan kelompok umur terbanyak usia 1-4 tahun (48\%). Dari 27 anak TB-HIV, 20 anak mempunyai status imunitas supresi berat dan 18 anak kategori C. Dua puluh anak menderita TB paru, 3 anak TB milier, 2 anak limfadenitis TB, 1 anak TB diseminata, dan 1 anak perikarditis TB. Lima belas anak mendapat pengobatan TB secara lengkap, 4 anak meninggal dunia, dengan penyebab kematian 1 orang karena pneumonia berat tersangka PCP dan 3 orang tersangka sepsis.

Kesimpulan. Diagnosis TB paru ditemukan sebesar 54\% pada penderita HIV, sehingga skrining rutin TB harus menjadi bagian penting dari diagnostik hasil pemeriksaan HIV. Sari Pediatri 2011;13(1):55-61.
\end{abstract}

Kata kunci: HIV, TB, anak

$\mathrm{P}$ andemi infeksi HIV menyebabkan peningkatan pelaporan TB secara bermakna di beberapa negara dengan perkiraan peningkatan insidens TB 20 kali lipat diantara anak yang terinfeksi HIV, dibandingkan dengan anak yang tidak

\footnotetext{
Alamat korespondensi:

Dr. Retno Widyaningsih, Sp.A. Kelompok Kerja Respirologi SMF Anak RSAB Harapan Kita. Jl. Let.Jen S. Parman Kav 87 Jakarta 11420. Telp (021) 566 8284. Fax (021) 5601802
}

terinfeksi HIV. ${ }^{1-4} \mathrm{Hal}$ ini berkaitan dengan keadaan imunokompromais pada infeksi HIV sebagai salah satu faktor risiko penyakit TB, yang mengakibatkan kerusakan sistem imun sehingga kuman TB yang dorman mengalami re-aktivasi. ${ }^{5}$

TB dan HIV pada anak merupakan penularan dari kasus orang dewasa, dan pola penyakit tersebut mencerminkan epidemi pada populasi orang dewasa. ${ }^{6-8}$ Pada tahun 1992, diperkirakan oleh Organisasi Kesehatan Dunia bahwa antara 9-11 juta orang dewasa dan 1 juta anak-anak terinfeksi HIV di negara 
berkembang, kebanyakan di daerah sub-Sahara. ${ }^{9}$ Dengan perkembangan ganda TB dan epidemi HIV, jumlah anak ko-infeksi TB dan HIV telah meningkat selama bertahun-tahun, sebagai akibat peningkatan prevalensi TB dan HIV pada wanita muda dan ibu. ${ }^{10-12}$ Oleh sebab itu HIV/AIDS menjadi ancaman utama terhadap pengendalian TB dan pencapaian $\mathrm{MDGs},{ }^{13}$ termasuk Indonesia.

Infeksi HIV menyebabkan diagnosis dan tatalaksana TB pada anak menjadi lebih sulit karena tanda atau gejala TB pada anak dengan HIV menjadi kurang spesifik sehingga tidak dapat dijadikan pedoman untuk mendiagnosis TB.

Penelitian ini bertujuan untuk menjabarkan karakteristik ko-infeksi TB dengan HIV pada anak di RSAB Harapan Kita Jakarta.

\section{Metode}

Penelitian deskriptif potong lintang, dengan sampel berasal dari rekam medik pasien rawat inap dan rawat jalan di RSAB Harapan Kita, sejak 2002-2010. Pasien yang diikutsertakan ke dalam penelitian adalah anak yang berumur 0-12 tahun, didiagnosis infeksi HIV oleh Kelompok Kerja Infeksi atau Alergi-Imunologi dan didiagnosis menderita penyakit TB oleh Kelompok Kerja Respirologi. Data yang dicatat meliputi faktor risiko infeksi dan sakit TB yaitu umur, parut BCG, kontak dengan pasien TB, status gizi, dan status imunitas HIV. Data lain yang dicatat yaitu gejala klinis HIV, gejala klinis TB, skor TB, pengobatan dan penyebab kematian. Data laboratorium meliputi hasil pemeriksaan BTA dan PCR Mycobacterium tuberculosis (M.tb) dari bilasan lambung dan biopsi aspirasi jarum kelenjar getah bening leher, serologi dan PCR HIV, prosentase CD4, serta foto Rontgen toraks.

\section{Definisi operasional}

Diagnosis HIV pada anak berdasarkan hasil pemeriksaan PCR RNA HIV, pemeriksaan serologi positif terhadap HIV dan ditunjang dengan pemeriksaan klinis terdapat gejala AIDS Related Illness (ARI). Kategori HIV dan status imunitas disesuaikan dengan klasifikasi CDC revisi 1994. Diagnosis TB berdasarkan gejala kronis sugestif $\mathrm{TB}$, pemeriksaan fisis sangat menunjang $\mathrm{TB}$, uji tuberkulin, laboratorium, dan foto Rontgen toraks sugestif TB.

\section{Hasil}

Sejak tahun 2002-2010, telah didiagnosis 50 anak yang terinfeksi HIV. Dua puluh tujuh orang anak (54\%) menderita penyakit TB, dengan jumlah anak perempuan lebih banyak dibandingkan anak laki-laki yaitu 3:1. Kelompok umur terbanyak adalah anak berusia $<5$ tahun sebanyak $81,4 \%$, sedangkan anak berusia $\geq 5$ tahun sebanyak $18,5 \%$. Penyakit TB yang

Tabel 1. Karakteristik pasien TB pada anak HIV (TBHIV)

\begin{tabular}{lc}
\hline Parameter & Jumlah $(\mathrm{n}=27)$ \\
\hline Kelompok umur & \\
$<12$ bulan & 9 \\
$1-4$ tahun & 13 \\
$5-12$ tahun & 5 \\
Jenis kelamin & \\
Laki-laki & 7 \\
Perempuan & 20 \\
Status gizi & \\
Buruk & 11 \\
Kurang & 14 \\
Baik & 2 \\
Status imunitas & \\
Tidak supresi & 3 \\
Supresi sedang & 4 \\
Supresi berat & 20 \\
Parut BCG & \\
Ada & 21 \\
Tidak ada & 6 \\
Kontak TB & \\
Ada & 13 \\
Tidak jelas & 11 \\
Disangkal & 3 \\
\hline
\end{tabular}

Tabel 2. Klasifikasi infeksi HIV pada anak: kategori status imunosupresi dan klinis CDC revisi 1994. (n=27)

\begin{tabular}{lcccc}
\hline Status imun & \multicolumn{4}{c}{ Usia } \\
\cline { 2 - 5 } & $\begin{array}{c}<12 \\
\text { bulan }\end{array}$ & $\begin{array}{c}1-4 \\
\text { tahun }\end{array}$ & $\begin{array}{c}5-12 \\
\text { tahun }\end{array}$ & Total \\
\hline Kategori imunosupresi & & & & \\
$\quad$ Tak ada supresi & 2 & 1 & 0 & 3 \\
Supresi sedang & 1 & 3 & 0 & 4 \\
Supresi berat & 5 & 12 & 3 & 20 \\
Kategori klinis & & & & \\
Kategori A & 1 & 2 & 1 & 4 \\
Kategori B & 1 & 4 & 0 & 5 \\
Kategori C & 6 & 8 & 4 & 18 \\
\hline
\end{tabular}


diderita di antaranya 20 anak menderita TB paru, 3 anak TB milier, 2 anak limfadenitis TB, 1 anak TB diseminata, dan 1 anak perikarditis TB. Parut BCG ditemukan pada 21 anak, dan uji tuberkulin positif $\geq 5 \mathrm{~mm}$ ditemukan hanya pada 5 anak. Anak yang terpajan dengan orang dewasa dengan TB aktif (kontak TB positif) didapatkan pada 13 orang anak. (Tabel 1)

Berdasarkan klasifikasi infeksi HIV pada anak (CDC revisi 1994), sebagian besar anak TB-HIV mempunyai status imunitas supresi berat (20 anak), 17 anak di antaranya berusia $<5$ tahun. Kategori A didapatkan pada 4 orang, kategori B pada 5 orang dan kategori $\mathrm{C}$ pada 18 orang. Status gizi buruk didapatkan pada 11 anak, gizi kurang 14 anak dan gizi baik pada 2 anak. (Tabel 1 dan 2)

Dari tabel 3 terlihat gejala klinis HIV dan TB mempunyai kemiripan gejala dan bertumpang tindih, di antaranya yang terbanyak dijumpai adalah demam lama (27 anak), batuk kronik (26 anak), diare berulang atau kronik (26), limfadenopati (19 anak) dan gizi buruk (11 anak). Dua orang anak mengalami infeksi oportunistik CMV dan 1 orang mengalami TB diseminata, keduanya berusia $<1$ tahun. Uji tuberkulin positif didapatkan hanya pada 5 anak. Pemeriksaan dari cairan lambung dari 13 orang anak, didapatkan BTA (+) pada 1 anak dan PCR M.tb (+) pada 7 anak, 14 anak lainnya tidak diperiksa karena tidak ada biaya. Pemeriksaan FNAB KGB leher didapatkan BTA (+) pada 2 anak. Gambaran radiologis toraks sugestif TB didapatkan pada 25 anak, berupa gambaran milier pada 3 anak, pembesaran kelenjar hilus pada 14 anak, bronkopneumonia pada 8 anak, dan 2 anak gambaran infiltrat minimal.

Pada penelitian ini, berdasarkan gejala klinis dan pemeriksaan penunjang pada anak TB-HIV didapatkan hasil sistem penilaian TB (scoring system) dengan nilai skor $\geq 6$ pada 17 anak. Tujuh anak mempunyai nilai skor $<6$ dengan uji tuberkulin negatif, mempunyai status imunosupresi berat, 5 anak dengan kategori C, 1 anak kategori B dan mempunyai gambaran foto Rontgen toraks sugestifTB. Satu anak dengan nilai skor 4 menderita TB diseminata dan 1 anak dengan nilai skor 5 didiagnosis limfadenitis TB berdasarkan BTA (+) dari pemeriksaan aspirasi jarum kelenjar getah bening leher. Lima anak lainnya mempunyai nilai skor 5 , berusia $<5$ tahun didiagnosis TB berdasarkan gejala klinis dan foto Rontgen toraks. Tiga anak tidak dimasukkan dalam skoring karena menderita TB milier.
Pada penelitian ini tercatat 14 anak menjalankan pengobatan OAT lengkap, 1 anak masih dalam pengobatan saat penelitian berlangsung, 3 anak dropout, 3 anak menolak pengobatan, 2 anak pindah ke luar kota dan 4 anak meninggal dunia sebelum pengobatan selesai. Semua anak yang mempunyai status imunosupresi berat juga mendapatkan terapi kotrimoksazol sebagai profilaksis PCP. Dari 14 anak yang selesai menjalankan pengobatan OAT lengkap, sebanyak 13 anak mendapat terapi ARV, 2 di antaranya menjalani rawat jalan ke RSCM. Pada penelitian ini didapatkan 4 orang anak TB-HIV meninggal dunia. Satu anak berusia $<1$ tahun meninggal karena

Tabel 3. Gejala klinis TB-HIV, pemeriksaan laboratorium, radiologis, dan skoring $\mathrm{TB}$

\begin{tabular}{|c|c|}
\hline Gejala klinis dan laboratorium & $\mathrm{n}=27$ \\
\hline \multicolumn{2}{|l|}{ Kontak TB } \\
\hline Ada & 13 \\
\hline Tidak jelas & 11 \\
\hline Kontak disangkal & 3 \\
\hline \multicolumn{2}{|l|}{ Uji tuberkulin } \\
\hline Positif $(\geq 5 \mathrm{~mm})$ & 5 \\
\hline$>0 \mathrm{~mm}-<5 \mathrm{~mm}$ & 1 \\
\hline Negatif $(0 \mathrm{~mm})$ & 21 \\
\hline \multicolumn{2}{|l|}{ Status gizi } \\
\hline Buruk & 11 \\
\hline Kurang & 14 \\
\hline Baik & 2 \\
\hline Demam lama & 27 \\
\hline Batuk kronik & 26 \\
\hline Diare kronik/berulang & 26 \\
\hline Pembesaran kel.limfe koli/aksial/inguinal & 19 \\
\hline Pembengkakan sendi & 0 \\
\hline \multicolumn{2}{|l|}{ BTA bilasan lambung } \\
\hline Positif & 1 \\
\hline Negatif & 12 \\
\hline Tidak diperiksa & 14 \\
\hline \multicolumn{2}{|l|}{ PCR TB bilasan lambung } \\
\hline Positif & 7 \\
\hline Negatif & 6 \\
\hline Tidak diperiksa & 14 \\
\hline Pemeriksaan FNAB KGB ditemukan BTA & 2 \\
\hline \multicolumn{2}{|l|}{ Gambaran radiologis } \\
\hline Milier & 3 \\
\hline Pembesaran kelenjar hilus & 14 \\
\hline Bronkopneumonia & 8 \\
\hline Infiltrat minimal & 2 \\
\hline \multicolumn{2}{|l|}{ Skoring TB } \\
\hline Skor $<6$ & 7 \\
\hline Skor $>6$ & 17 \\
\hline
\end{tabular}


Tabel 4. Outcome pengobatan TB pada anak TB-HIV

\begin{tabular}{lc}
\hline Outcome pengobatan OAT & $(\mathrm{n}=27)$ \\
\hline Pengobatan lengkap & 14 \\
Meninggal sebelum pengobatan selesai & 4 \\
Masih dalam pengobatan & 1 \\
Drop out & 3 \\
Menolak pengobatan & 3 \\
Pindah ke luar kota & 2 \\
\hline
\end{tabular}

pneumonia berat tersangka Pneumocystis carinii jiroveci Pneumonia (PCP). Tiga anak lainnya meninggal karena tersangka sepsis, 1 anak berusia $<1$ tahun dan 2 anak berusia $>5$ tahun (Tabel 4 ).

\section{Pembahasan}

Tuberkulosis merupakan salah satu infeksi oportunistik utama yang berpengaruh pada morbiditas dan mortalitas penderita infeksi HIV/AIDS di negaranegara berkembang termasuk di Indonesia, dan merupakan penyebab $30 \%$ kematian pada populasi AIDS. Hasil survei yang dilakukan oleh Departemen Kesehatan di beberapa propinsi menunjukkan angka ko-infeksi TB-HIV yang bervariasi, yaitu $24 \%$ di Bali, 32\% di Jawa Timur, dan $10 \%$ di Jakarta. ${ }^{14,15}$ Pada penelitian kami didapatkan 54\% prevalensi TB pada pasien HIV dengan kelompok umur terbanyak adalah anak berusia $<5$ tahun $(81,4 \%)$. Keadaan tersebut hampir sebanding dengan penelitian salah satu Rumah Sakit Pendidikan di Republik Kongo yang mendapatkan ko-infeksi TB-HIV pada anak sebesar $65 \% .^{16}$

Status imunosupresi HIV dibagi berdasarkan sistem klasifikasi infeksi HIV berupa penurunan jumlah dan prosentase CD $4 .{ }^{17}$ Penurunan fungsi sistem imun menyebabkan terjadinya infeksi oportunistik serta gangguan fungsi berbagai organ tubuh secara langsung atau tidak langsung. Penelitian kami menemukan status imunosupresi berat pada 20 orang anak, di antaranya 2 orang mengalami infeksi oportunistik CMV, 1 orang mengalami TB diseminata, 3 orang TB milier, dan pneumonia pada 8 orang anak. Berdasarkan kategori klinis HIV sebagian besar termasuk dalam kategori C yaitu 18 orang, sedangkan kategori A 4 orang, dan B 5 orang.

Manifestasi klinis ko-infeksi TB dan HIV tergantung dari stadium infeksi HIV dan derajat beratnya defisiensi imunitas yang terjadi. Pada stadium awal dengan defisiensi imun ringan sampai sedang, tanda dan gejala tidak berbeda dengan anak tanpa HIV. Pada keadaan defisiensi imun berat maka akan terjadi peningkatan frekuensi penyakit paru yang menyerupai TB primer dan TB ektrapulmonal termasuk penyakit TB diseminata. ${ }^{5,18}$

Presentasi klinis TB dan infeksi HIV dapat terlihat sebagai demam lama yang persisten, penurunan berat badan (malnutrisi), limfadenopati dan pneumonia. Gejala tersebut merupakan gejala yang paling umum di kedua penyakit. ${ }^{6}$ Presentasi klinis terbanyak pada penelitian ini serupa dengan presentasi klinis beberapa penelitian lainnya, ${ }^{5,6}$ yaitu demam lama, batuk kronik, diare berulang atau kronik dan limfadenopati. Status gizi buruk terdapat pada 11 pasien dan gizi kurang pada 14 pasien.

Diagnosis TB pada anak sulit, terlebih pada anak dengan ko-infeksi TB dan HIV. Diagnosis pasti ditegakkan dengan ditemukannya $M . t b$ pada kultur. Pada anak, kesulitan menegakkan diagnosis pasti disebabkan oleh dua hal, yaitu sedikitnya jumlah kuman (paucibacillary) dan sulitnya pengambilan spesimen (sputum). Hal ini disebabkan karena bayi dan anak tidak dapat mengeluarkan sputum untuk pemeriksaan mikroskopis dan kultur. Pada satu penelitian, hanya didapatkan sebanyak 5\% kultur positif pada anak dengan terapi TB melalui pemeriksaan aspirasi cairan lambung. ${ }^{14,19}$ Telah banyak pemeriksaan penunjang untuk membantu diagnosis TB anak seperti uji serologis dan PCR, tetapi hasilnya sampai saat ini belum memuaskan; belum ada satupun pemeriksaan penunjang yang dapat memberi informasi aktif tidaknya TB anak. ${ }^{5}$

Pada penelitian kami, tidak semua anak dapat dilakukan pemeriksaan aspirasi cairan lambung, sebagian besar karena kesulitan biaya. Dari 13 anak yang diperiksa, didapatkan BTA positif hanya pada 1 anak, dan kultur M.Tb seluruhnya negatif. Kesulitan mendapatkan kepastian bakteriologik membuat peneliti mencoba untuk memeriksa PCR M.tb dari cairan lambung, dan didapatkan positif pada 7 anak. Pada pasien TB dewasa, metode pemeriksaan PCR telah terbukti mempunyai sensitivitas dan spesifitas yang cukup tinggi, akan tetapi peranannya dalam diagnosis TB anak masih kontroversial dan memerlukan penelitian lebih lanjut. ${ }^{5}$ Apakah hasil PCR M.tb mempunyai arti klinis, dalam hal ini peneliti berpendapat bahwa dengan adanya kesulitan diagnosis 
TB pada HIV, maka hasil PCR M.tb cairan lambung pada penelitian ini dapat digunakan untuk membantu menegakkan diagnosis.

Pendekatan diagnosis TB pada anak dengan HIV pada prinsipnya sama dengan pasien anak tanpa HIV, yaitu adanya gejala kronis sugestif TB, hasil pemeriksaan fisis yang sangat menunjang TB, hasil uji tuberkulin $\geq 5 \mathrm{~mm}$, dan foto Rontgen toraks sugestifTB. Dengan mengetahuinya hal tersebut, maka diharapkan dapat menjadi pedoman untuk menentukan diagnostik TB pada anak dengan HIV. ${ }^{5}$

Di Afrika Selatan dengan adanya kesulitan mendapat konfirmasi pemeriksaan bakteriologik, mencari riwayat kontak dengan TB dewasa, serta hasil uji tuberkulin yang sering negatif, maka diagnosis TB pada anak HIV menjadi diagnosis presumtif berdasarkan gejala klinis dan interpretasi foto toraks. ${ }^{20,21}$ Kesulitan mendiagnosis TB pada anak HIV juga menjadi permasalahan pada penelitian ini, sehingga diagnosis TB pada anak dengan HIV merupakan diagnosis presumtif berdasarkan gejala klinis, laboratorium, dan foto toraks.

Sistem skoring sebagai alat skrining lebih berguna pada daerah dengan endemisitas TB yang rendah, dan tidak begitu berguna pada daerah endemis dengan prevalens ko-infeksi TB dan HIV yang tinggi. ${ }^{20-22}$ Pada penelitian ini dicoba untuk melihat kegunaan sistem skoring TB yang dibuat oleh UKK Respirologi IDAI, walaupun diketahui tanda dan gejala TB pada infeksi HIV mempunyai nilai karakteristik yang kurang sensitif dan spesifik. Pada sistem skoring, anak didiagnosis TB jika jumlah skor $\geq 6$, (skor maksimal 13), pembobotan tertinggi terletak pada uji tuberkulin dan adanya kontak TB dengan BTA positif. 5

Uji tuberkulin jarang positif pada infeksi HIV karena anergi, dan pada penelitian ini didapatkan hanya positif pada 5 pasien. Namun ternyata walaupun uji tuberkulin positif hanya didapatkan pada 5 anak, hasil skor $\mathrm{TB} \geq 6$ didapatkan pada sebagian besar kasus yaitu pada 17 anak. Hal ini disebabkan karena parameter gejala demam lama, batuk lama, limfadenopati serta gizi buruk merupakan gejala dominan pada sebagian besar kasus ko-infeksi TB-HIV, sehingga memberi bobot yang tinggi pada skoring.

Riwayat kontak dengan sumber kasus TB dewasa sering ditemukan sebagai petunjuk diagnosis awal. Pasien TB dewasa dengan BTA positif dapat menjadi sumber penularan yang utama karena berdasarkan penelitian akan menularkan sekitar $65 \%$ orang di sekitarnya. ${ }^{5}$ Sekitar $60 \%$ anak yang terinfeksi HIV memiliki kontak yang dikenal, ${ }^{23}$ dan dari parameter kontak TB pada penelitian ini didapatkan $48 \%$ kasus.

Gambaran dasar radiologis TB tetap sama seperti anak-anak yang tidak terinfeksi HIV, namun interpretasi seringkali lebih sulit karena pada anak dengan infeksi HIV terkait penyakit paru lain yang mungkin mirip dengan TB (misalnya Lymphoid Interstitial Pneumonitis/LIP, pneumonia bakteri dan bronkiektasis). Pola miliaria reticulonodular dengan atau tanpa limfadenopati bisa terdapat pada TB milier atau LIP. Pada bayi paling sering adalah TB milier, sedangkan pada anak $>2$ tahun terdapat pembengkakan parotis dan clubbing paling mungkin adalah LIP. ${ }^{19}$ Pada sistem skoring, parameter foto toraks adalah bila ditemukan gambaran sugestif TB berupa: pembesaran kelenjar hilus atau paratrakeal dengan/ tanpa infiltrat, konsolidasi, milier, kalsifikasi dengan infiltrat, atelektasis, atau tuberkuloma. Pada penelitian ini gambaran radiologis sugestif TB didapatkan pada hampir seluruh kasus kecuali 2 anak dengan gambaran infiltrat minimal.

Penelitian di Zambia, TB pada anak dengan HIV uji tuberkulin positif didapatkan hanya pada $9 \%$ kasus dan penggunaan Pediatric Tuberculosis Score Chart pada anak TB-HIV didapatkan sensitivitas sebesar $88 \%$ dan spesifitas hanya $25 \%$. Hal ini disebabkan karena gejala klinis HIV yang saling bercampur-aduk dengan TB dan kegunaan beberapa kriteria penting untuk mendiagnosis TB seperti tuberkulin dan foto toraks menjadi berkurang. ${ }^{24}$ Seperti di Zambia yang merupakan daerah endemis HIV, tampaknya sistem skoring pada penelitian ini tidak dapat digunakan sebagai alat diagnostik karena rendahnya spesifisitas.

Rekomendasi pengobatan TB pada anak terinfeksi HIV saat ini sama dengan pengobatan untuk anak tanpa infeksi HIV. Pengobatan dibagi menjadi dua fase, yaitu fase intensif selama 2 bulan, dilanjutkan dengan fase kontinu selama 4 bulan. Total lama pemberian OAT adalah 6-9 bulan. Lama pemberian ini juga tergantung pada berat/ luasnya penyakit TB, BTA positif atau negatif, dan keterkaitan dengan HIV. Respons klinis, radiologis dan mikrobiologi terhadap pengobatan sebaiknya dievaluasi sebelum pengobatan dihentikan pada akhir bulan ke-6. Jika respons klinis atau radiologis masih buruk, atau biakan $M . T b$ positif setelah fase intensif pengobatan, pemberian OAT harus diteruskan paling sedikit 9 bulan. ${ }^{5}$ 
Pada penelitian ini, pengobatan TB secara lengkap hanya diikuti oleh 15 anak, 3 anak menolak pengobatan, 3 anak drop-out, 2 anak pindah ke luar kota dan 4 anak meninggal dunia. Kepatuhan berobat yang sulit untuk dijalankan menjadi masalah dalam penelitian ini dan juga menjadi kegagalan di kedua kondisi ini. Sebagian besar anak-anak dalam penelitian ini, satu atau kedua orangtuanya sudah meninggal dunia karena penyakit HIV, sehingga pengasuhan diambil alih oleh pihak keluarga. Seperti halnya di Afrika Selatan, ${ }^{20}$ pada penelitian ini faktor kematian orangtua menjadi salah satu alasan mengapa sebagian besar anak TB-HIV tidak mendapat pengobatan. Selain itu masalah finansial dan tidak tersedianya ARV di sektor kesehatan perifer juga menjadi penyulit dalam berkomitmen. Oleh sebab itu sebelum memulai pengobatan, baik OAT maupun ARV, ditegaskan untuk berkomitmen dalam kepatuhan berobat dengan semua kesulitan yang akan dihadapi.

Kematian langsung akibat TB tidak didapatkan pada penelitian ini, namun karena semua anak dalam keadaan imunosupresi berat, maka kemungkinan ko-infeksi dengan patogen lain sebagai penyebab kematian sangat mungkin. Terdapat 4 anak meninggal dunia, 3 anak tersangka sepsis dan 1 anak mengalami pneumonia berat dengan gambaran infiltrat luas pada kedua lapang paru, tidak respon terhadap pengobatan antibiotik dan akhirnya meninggal dengan diagnosis presumtif tersangka PCP. Dari data kematian penelitian ini, terlihat perlunya diagnosis dini dan pengobatan TB pada semua pasien terinfeksi HIV, terutama ketika pola klinis hitung sel CD4 menunjukkan imunosupresi berat.

\section{Kesimpulan}

Tuberkulosis merupakan infeksi oportunistik yang sering terjadi dengan morbiditas dan mortalitas cukup tinggi pada anak HIV di RSAB Harapan Kita. Diagnosis infeksi dan sakit TB pada anak yang terinfeksi HIV sangat sulit sehingga skrining rutin TB harus menjadi bagian penting dari diagnostik hasil pemeriksaan terhadap setiap anak HIV. Perlu pendataan medis yang lebih lengkap, mulai dari awal penyakit, faktor risiko infeksi $\mathrm{TB}$, perjalanan penyakit, pemantauan pengobatan dan outcomenya. Data ini bermanfaat dan dapat menjadi sumber untuk penelitian lebih lanjut.

\section{Daftar pustaka}

1. Chintu C, Mudenda V, Lucas S. Lung diseases at necropsy in African children dying from respiratory illnesses: a descriptive necropsy study. Lancet 2002; 360:985-90.

2. Palme IB, Gudetta B, Bruchfeld J, Muhe L, Giesecke J. Impact of human immunodeficiency virus 1 infection on clinical presentation, treatment outcome and survival in a cohort of Ethiopian children with tuberculosis. Pediatr Infect Dis J 2002; 21:1053-61.

3. Jeena PM, Pillay P, Pillay T, Coovadia HM. Impact of HIV-1 coinfection on presentation and hospital-related mortality in children with culture proven pulmonary tuberculosis in Durban, South Africa. Int J Tuberc Lung Dis 2002; 6:672-8.

4. Madhi SA, Petersen K, Madhi A, Khoosal M, Klugman $\mathrm{KP}$. Increased disease burden and antibiotic resistance of bacteria causing severe community-acquired lower respiratory tract infections in human immunodeficiency virus type 1-infected children. Clin Infect Dis 2000; 31:170-6.

5. Nastiti N Rahajoe, Darfioes Basir, Makmuri MS, Cissy B Kartasasmita. Tuberkulosis dengan HIV. Pedoman Nasional Tuberkulosis Anak Edisi-2 dengan Revisi, UKK Pulmonologi PP IDAI, September 2008.

6. Chifumbe C. Tuberculosis and human immunodeficiency virus co-infection in children: management challenges. Pediatric Respiratory Reviews 2007; 8:142-7.

7. Van Rie A, Beyers N, Gie RP, Kunneke M, Zietsman L, Donald PR.Childhood tuberculosis in an urban population in South Africa: burdenand risk factor. Arch Dis Child 1999; 80: 433-437.

8. Kabra SK, Lodha R, Seth V. Some current concepts on childhood tuberculosis. Indian J Med Res 2004; 120: 387-97.

9. World Health Organization Global Programme on AIDS. Current and future dimensions of HIV/ AIDS Pandemic. A Capsule Summary Document. GPA/RES/SF/92.1 1992a. Geneva: World Health Organization.

10. Ahmed Y, Mwaba P, Chintu C, Grange JM, Ustianowski A, Zumla A. A study of maternal mortality at the University Teaching Hospital, Lusaka, Zambia: the emergency of tuberculosis as a major nonobstetric cause of maternal death. Int J Tuberc Lung Dis 1999; 3:675-80.

11. Pillay T, Khan M, Moodley J, Adhikari M, Coovadia H. Perinatal tuberculosis and HIV-1: considerations for resource-limited settings. Lancet Infect Dis 2004; 4: 
155-65.

12. Katumba-Lunyenya J, Joss V, Latham P, Abbatnan C. Pulmonary tuberculosis and extreme prematurity. Arch Dis Child Fetal Neonatal Ed 2005; 90: F179-83.

13. Hecht R, Alban A, Taylor K, Post S, Andersen BN, Schwarz R. Putting it together: AIDS and the Millennium Development Goals. PLoS Med 2006; 3: e455.

14. World Health Organization (WHO). Global Tuberculosis Control Surveillance, planning, financing: WHO Report 2006. WHO/HTM/TB/2006.362. Genewa: WHO, 2006.

15. Elizabeth LC, Catherine JW, Neff W, Dermot M, Brian G. W, Mario C. Raviglione, Christopher D. The Growing Burden of Tuberculosis, Global Trends and Interactions With the HIV Epidemic. Arch Intern Med 2003;163:1009-21.

16. M'Pemba LLAB, Mabiala B, Bantsimba T, Nzingoula S. Tuberculosis and HIV/AIDS co-infection in children: experience carried out in paediatric service of the teaching hospital of Brazzaville, Republic of Congo (1995-2004). Bull Soc Pathol Exot 2007;100:51-2.

17. Akib AAP. Infeksi HIV pada Bayi dan Anak. Sari Pediatri 2004; (Suplement); 1-14.

18. Dermot M, Anthony H, Haileyesus G. Tuberculosis and HIV interaction in sub-Saharan Africa: impact on patients and programmes; implications for policies. Tropical Medicine and International Health volume 10 no 8 pp 734-742 august 2005.

19. Schaaf HS, Cotton MF. The diagnosis and management of tuberculosis in HIV-infected children. The Southern African Journal of Epidemiology and Infection 2006; 21:9-13.

20. B. J. Marais, S. M. Graham, M. F. Cotton, and N. Beyers. Diagnostic and Management Challenges for Childhood Tuberculosis in the Era of HIV. The Journal of Infectious Diseases 2007; 196:S76-85

21. B.J. Marais, H. Rabie, M.F. Cotton. Mini-symposium: Childhood TB in 2010. TB and HIV in children advances in prevention and management. Paediatric Respiratory Reviews 2011;12: 39-45.

22. S.K. Sharma and A. Mohan. Co-infection of Human Immunodeficiency Virus (HIV) and Tuberculosis: Indian Perspective. Indian J Tuberc 2004; 51:5-16.

23. Hesseling AC, Werschkul H, Westra A. The clinical features and outcome of confirmed tuberculosis in HIV-infected children. Int J Tuberc Lung Dis 2002; 6(Suppl 1): S181.

24. Rheenen P. The use of paediatric tuberculosis score chart in an HIV-endemic area. Tropical Medicine and International Health,2002: 435-41. 